\title{
SOLIDARITY DILEMMAS IN TIMES OF AUSTERITY: Auto-ethnographic Interventions
}

\section{DIMITRIOS THEODOSSOPOULOS University of Kent, UK \\ (iD) https:/ / orcid.org/0000-0001-8453-3450}

There is a split in myself that has troubled my anthropological engagements with solidarity initiatives in crisis-afflicted Greece. It is between two authorial voices that compete in structuring and influencing my writing: the first adopts a rigid, uncompromising stance regarding power, while the second considers strategic compromise as an essential part of protracted resistance. The first voice criticizes my second authorial voice for being a bourgeois socialist of sorts, for example, in embracing the humanitarian possibility. The second voice disapproves of the hard ideological stance of the former, especially his dogmatic rejection of humanitarian solidarity as "philanthropy in disguise."

To address this emerging contradiction, I make use of - and share with the readership of this journal - an innovative analytical tool that foregrounds the ambivalence and codependence of competing ideological positions in ethnographic writing. Rather than hiding the authorial split I describe above, I take advantage of the representational possibilities it engenders. The split itself, I will demonstrate, results from parallel conversations between the ethnographer and their interlocutors in the field. The emerging dialectic - an exchange of opposing views in intersubjective ambiguity (Jackson 1998) — serves here as an ethnographic device that facilitates the analysis of local disagreements, but in a manner that challenges 
the limitations of singular representation and "the reduction of social life to fixed forms" (Williams 1977, 129). Making visible the conflicting predilections of the author (and the degree to which these are constituted in dialogue with his respondents) serves as a remedy against the bias of singular representation and the concomitant colonial vision of the "lonely" ethnographer (Rosaldo 1989).

Most ethnographers recognize those moments when they - and the people they study - feel divided in identifying with more than one argument or type of practice. Sometimes, the plurality of such identifications can be traced within the narratives of the same anthropological respondent, but also, within the conflicting commitments of the same anthropological author. Reflexive attention to such plural views can unravel the multiple layers of consciousness that shape the ethnographic outcome (Jackson 1998; Bochner and Ellis 2016), as well as specify and undermine the authenticity of the author as knower (Fabian 1983; Clifford and Marcus 1986; Davies 1998). The auto-ethnographic approach opens the way for treating the authorial self as a resource (Collins and Gallinat 2010), adding transparency to the interrelationship between the researcher and the researched (see Okely and Callaway 1992; Reed-Danahay 1997). The authorial split I introduce below builds on these previous perspectives to provide a representational lens for seeing others through more than one self-critical anthropological self, which take responsibility for the complicit interrelationship between the ethnographer and their interlocutors in the field (Marcus 1997).

In this article, I test the effectiveness of the analytical tool introduced here against a set of irresolvable dilemmas that emerged from the context of humanitarian solidarity initiatives in austerity-stricken Greece. That is, the voluntary, grassroots associations of citizens acting together to provide support-psychological or legal advice, food, clothes, medicine - to refugees, migrants, or fellow citizens severely afflicted by austerity. ${ }^{1}$ To depart from hierarchical conceptualizations of humanitarianism, most local initiatives have embraced the term solidarity, radicalizing their ideological foundation (see Rakopoulos 2016; Rozakou 2018b). Emerging from this radicalization, the dilemmas addressed here embrace contradictory views about the emancipatory or compromising dimensions of humanitarian giving, as well as wider issues regarding resistance to austerity politics. For example, should we conceive the prolonged dependency on aid of impoverished citizens (or the whole Greek nation) as complicity with hegemony? Or does such dependency perhaps constitute a form of strategic compromise - a respite from straightforward opposition - that provides scope and time for a reawakening social consciousness? 
The questions I outline here point toward the cyclical interweaving of resistance and compromise, and remind us of the Foucauldian axiom that resistance cannot be separated from power (Foucault 1978, 95; see also Abu-Lughod 1990). Anthropological analyses of resistance indicate that resistance is not the opposite of domination — or, I would add, the opposite of compromise. Local opposition to power is not autonomous of the wider cultural and politico-economic relationships resisted in the first place (Keesing 1992; Gledhill 1994, 2012; Ortner 1995; Theodossopoulos 2015). In practice, however, such a nuanced and sophisticated view of the interplay between resistance and compromise can inform more than one argument in opposition. The persuasiveness of such arguments, as these are articulated during anthropological fieldwork, has generated the authorial split I outline here. Allow me to draw the parameters of this ideological disagreement.

\section{THE SPLIT}

The first analytical voice within me that has shaped this article is a self-centered voice, authoritative and guided by uncompromising Marxist principles. It superimposes an interpretation of complicity with hegemonic neoliberalism on other people's political choices - a sort of false consciousness, so to speak. I refer to this voice in my mind as the "uncompromising author," although my other authorial self has another name for him: the "pathologizing author," a label that marks a certain authorial arrogance and a failure to appreciate the nuanced meaningfulness of compromise at the local level. The analytical notion of false consciousness has pathologizing characteristics (Theodossopoulos 2015), as it assumes that the other does not know the nature of their exploitation — at least, not as clearly as the author. My uncompromising authorial self bristles at the burden of such critical self-accusations. He desires to rescue the notion of false consciousness from its pathologizing liabilities. This ambition represents a move in the direction of a wider reflexive-Marxist project, toward which this article takes a small step.

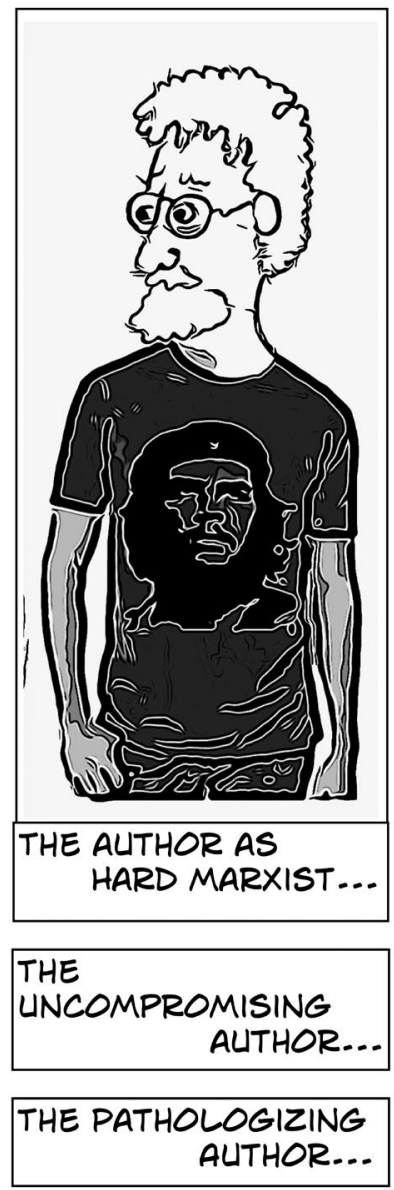




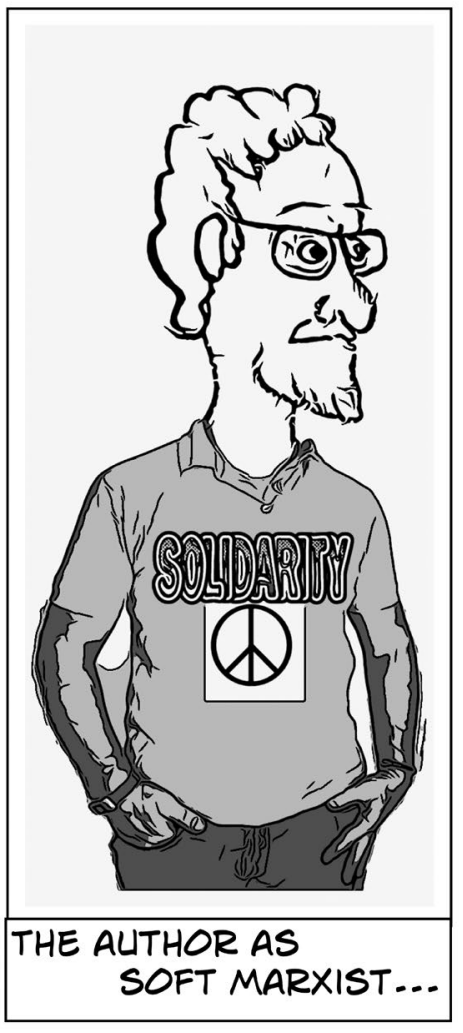

THE RATIONALIZING AUTHOR

The second author within me prefers a bottom-up approach that foregrounds the situated rationality of social actors and fieldwork interlocutors. He is a "lefty," particularly concerned about challenges set by inequality, but open to flexible solutions, even if these constitute partial compromises. I refer to the second voice in my mind as the "rationalizing author," as he is frequently accused-by my hard-Marxist authorial voice-of producing an apology for people's compromise and inaction (disguised as a grassroots perspective). Despite such criticisms, the rationalizing author persistently unearths undiscovered sets of meaning from local, unofficial conversation: the interpretations of his socially and politically emplaced interlocutors. "Yes, it is true, some of these interpretations seem like rationalizations," admits my soft-Marxist self, "but the job of the anthropologist is to make sense of this mess."

\section{REPRESENTATIONAL TOOLS}

I would like to introduce the authorial fragmentation presented above as an analytical tool that makes visible a productive infighting - a tussle within one's mind - generated by the overpowering persuasiveness of local arguments in tension. I will lay out the rationale of this autobiographical device for the benefit of other researchers who seek to capture ethnographically the coexistence of plural ideological identifications. In this article, the local identifications in question emerge from a discursive trajectory about compromise and solidarity that involves many local voices in the austerity-stricken city of Patras. ${ }^{2}$ The voices of my debating interlocutors from Patras resonate with the two authorial voices in my head, ${ }^{3}$ and lead me to believe that my pathologizing and rationalizing authorial identities are not isolated from each other (or from the local points of view that generated them), but that they have resulted from an intersubjective crystallization of ideas. 
Solidarians in Patras do not merely juxtapose the two positions outlined: they navigate through them and the dilemmas they engender with admirable pragmatism and flexibility (Papataxiarchis 2018; see also Cabot 2016; Rozakou 2016b; Rakopoulos 2018). Instead of reducing the emerging debates to a singular interpretation - as if one or the other argument has to prevail - I choose to underline here their unresolved nature, taking responsibility for the resulting ideological reduction structured by my authorial split. Through this reflexive approach, the dichotomy that the author artificially inflates becomes the object of caricature: a reduction registered and exposed.

The narrative technique of exposing a caricature by caricaturing invites us to consider the advantages of another representational tool employed in this article: graphic ethnography. The latter is a rapidly expanding approach that embraces ethnographically more than one form, the written and the graphic (Marcus 2017). ${ }^{4}$ The combination of text and drawing brings to the fore ethnographic details that might otherwise pass unnoticed. The panels that follow, for example, remind the reader that the voices of our respondents emerge sometimes in ideologically motivated conversations. The latter may sometimes take place over food and drink; they may be more or less emotionally charged - triggering particular body postures, including the subtle or emphatic reposition of heads or hands. In this respect, the graphic medium can remind the reader that in conversations we all do more than express opinions: we share and debate ideas with friends, attempt to persuade, flatter, or compromise. The image of the ethnographer in the graphic frame serves as a further reminder that the ethnographic product - or the authorial split, in this case-is co-authored, the result of an ongoing conversation.

My particular use of graphic ethnography in this article makes available components of the original ethnographic discussions presented as integral to the ethnographic narrative. They reanimate but also destabilize the authoritativeness of ethnographic interpretation, opening, rather than closing, ethnographic imagination (Ingold 2011, 2012). To escape from overidentification with particular positions - a problem related to the topic I tackle here-I have mirrored the emerging dilemmas on one's self: setting my protagonists, and myself, against their previous views, to escape momentarily from the performative certainty of arguing particular positions. To the extent that the graphic medium trades in reductions, it can-almost as easily_-showcase internal complexity, accentuating a sense of incompleteness (Taussig 2011; Theodossopoulos 2016a) as well as a sense of ethnographic openness (see graphic panel below). 


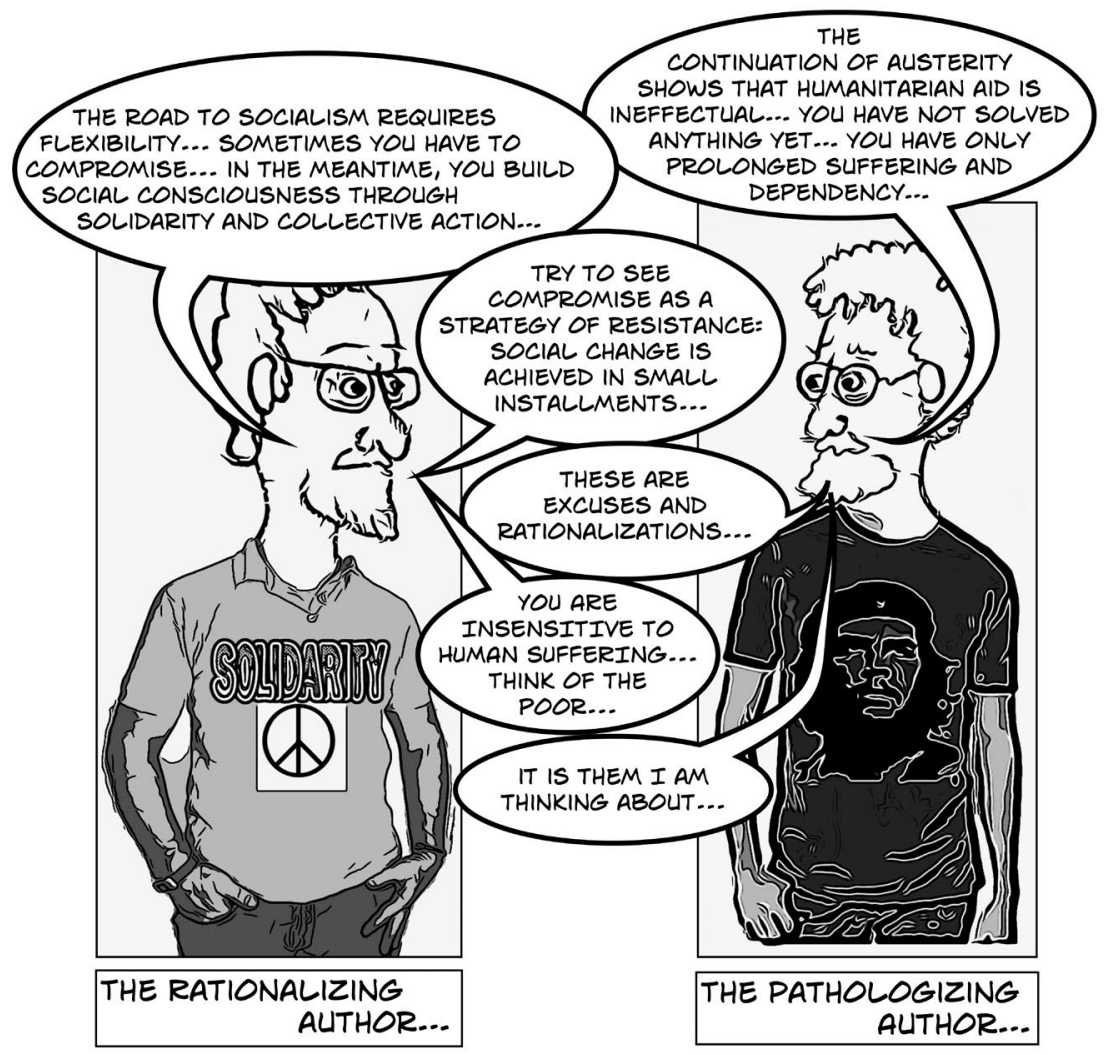

Parergon (a): The label "rationalizing author" and my use of the term
"rationalization" in this article require further clarification. Such terms are
delivered here with self-irony to problematize any potential implication of
academic analysis with hegemony. According to such a critical
perspective, explanations or practices that do not directly challenge the
dominant politico-economic system are exonerating excuses for inaction.
As a variant of the "false consciousness" thesis, this type of criticism can
carry forward a sense of patronizing dismissal of local rationality: e.g.,
"they can't see their own exploitation, but the author can." This is exactly
why my soft-Marxist self addresses the hard-Marxist self as
"pathologizing." It is only fair to allow the hard-Marxist self to
reciprocate, by "de-rationalizing" his counterpart in a patronizing manner.
The two caricatures here represent a heuristic technique that encourages a
self-reflexive analysis: caricaturing becomes a mirroring tool that exposes
the caricature.

Graphic ethnography panels work synergistically with the main text in a way that resembles how Neni Panourgiá (1995, xx, 2009) uses parerga (singular, parergon), that is, as work presented "alongside, another, main work" to offer an ad- 
ditional perspective and aid the analysis. Following Panourgiá, I use the technique of parerga to support some of my graphic panels, offering further commentary and contextualization. The combination of these three analytical tools - graphic ethnography, the parerga, and the authorial split - intends to challenge the singularity of anthropological representation. All three tools rely on reflexivity to generate a unified, self-critical effect that allows the author to coconstruct their object of study with respondents (see Okely and Callaway 1992; Reed-Danahay 1997; Davies 1998; Collins and Gallinat 2010). Notably, reflexivity is not merely a remedy against the biases generated by the invisible use of the authorial filter; it also foregrounds a more nuanced view of the other. Far from advancing self-absorption, self-critical reflexivity can generate - to turn Clifford Geertz's $(1989,2)$ aphorism on its head_- "plain and unpretending" anthropological texts.

\section{GREEK SOLIDARITY DILEMMAS: Anthropological Insights}

The growth of grassroots humanitarian initiatives in austerity-afflicted Greece has brought attention to the emancipatory role of solidarity as a concept that reconciles an ideological wariness toward philanthropy and the institutionalization of aid. An emerging body of anthropological work has registered this reawakening of solidarity in Greece. I employ this literature here as a comparative conceptual context to explore the ideological dilemmas of my solidarian respondents in Patras, an urban center troubled by austerity. Considering that my ethnographic exploration focuses specifically on the narratives of the supporters of two political parties in the period between 2015 and 2018, ${ }^{5}$ the discussion that follows expands the temporal and geographic scope of my analysis by bringing together insights from other anthropological work. ${ }^{6}$ But let me start by outlining the impact of the Marxist perspective on Greek ideas about solidarity.

The basic premises of the Marxist critique of philanthropy are familiar to several solidarians who participate in initiatives that aim to ameliorate the consequences of austerity in Greece. The original critique can be traced back to The Communist Manifesto, in which Karl Marx and Friedrich Engels (1998) pointed out that philanthropic charity (of the bourgeois-socialist variety) facilitates and reproduces existing capitalist hierarchies. Many theorists have echoed and developed this critique in the past 160 years, ${ }^{7}$ Slavoj Žižek most prominent among them. He identifies charity as a facilitating and redemptive constituent of the contemporary capitalist economy (Žižek 2009). In Greece, the Communist Party has communicated Marxist ideas to the wider community, including the critique of bourgeois 
philanthropy, which at the local level informs spontaneous discussions about the ethics of solidarity among left-leaning solidarians.

This long-established Marxist-inspired critique has generated a desire among Greek social actors involved in the aid and voluntary sector to replace the hierarchical notion of philanthropy $(\varphi \imath \lambda \alpha \nu \theta \rho \omega \pi i \alpha)$ with the more horizontal concept of solidarity ( $\alpha \lambda \lambda \eta \lambda \varepsilon \gamma \gamma v \dot{\eta})$. In late twentieth-century Greece, solidarity was associated narrowly with the anarchist and anti-authoritarian movements, but it acquired a new relevance in the early twenty-first century with the influx of immigrants and refugees and the introduction of antisocial austerity measures following the debt crisis (Rozakou 2018b, 189-90). This shift has resulted in the semiotic amplification of the term to embrace a wider array of progressive, antisystemic action (Rakopoulos 2018). The term solidarian ( $\alpha \lambda \lambda \eta \lambda \dot{\varepsilon} \gamma \gamma v o \varsigma)$, an adjective turned into a noun, is a neologism that captures this antisystemic dynamic (Rakopoulos 2016; Rozakou 2017, 2018b).

Recent anthropological work has brought analytical attention to the subtle and nuanced dimensions of this reanimated ethos of solidarity that proliferates in austerity-ridden Greece. To draw attention to its emancipatory and transformative possibilities, Theodoros Rakopoulos (2016) frames the notion of solidarity theoretically as a "bridge-concept" that unites diverse ideological elements with local practices embedded in social relationships. The renewed popularity of the concept among Greek activists reflects a desire to evade the inflexibility of formal institutions and the hierarchies of giving (implicit in humanitarian aid). Emerging as a politically aware alternative to philanthropy, solidarity serves as an inspirational principle that provides "a form of political education" realized through collective grassroots action (Rakopoulos 2016, 143). Rakopoulos's work provides us with examples of activist mobilization that aims to subvert austerity through alternative forms of food distribution. ${ }^{8}$

An overwhelming majority of Greek humanitarian actors affiliated with the left, volunteers and professional aid workers, have replaced philanthropy with solidarity in their vocabulary and practice - in fact, as Rakopoulos $(2016,146)$ observes, even philanthropists have dropped the vocabulary of charity. Nevertheless, many solidarians remain doubtful about the degree to which humanitarian solidarity can truly erase the connotations of philanthropy (Theodossopoulos 2016b): Has solidarity simply become another word for philanthropy? ${ }^{9}$ Heath Cabot provides us with a helpful metaphor to conceptualize this particular dilemma. Urban Greek solidarians are aware of the "two-facedness" inherent in the ethics of giving: solidarity inspires collective action, but it is also "tied to" "neoliberalism and austerity" 
(Cabot 2016, 153). This two-part realization generates a Janus-face effect, argues Cabot, one ridden with ambivalence. Cabot's Athenian respondents - volunteers in social clinics and social pharmacies - do not see solidarity as a remedy for the crisis, but rather as another one of its aspects, one intimately linked to dominant forms of neoliberal injustice. Such nuanced local views can help us appreciate that solidarity initiatives in Greece generate a political awareness nurturing a productive self-critique: participating in humanitarian solidarity is not a radical break from neoliberal austerity, and many solidarians are self-aware of these limitations (Cabot 2013, 2014).

The dilemma outlined above has deeper roots. In the Greek humanitarian and volunteering context, the concept of solidarity has a rival: hospitality ( $\varphi \imath \lambda o \xi \varepsilon v i ́ \alpha)$ toward strangers. In fact, solidarity's antihierarchical connotations become more visible when contrasted with hospitality, which is deeply implicated with the inequality of gift-giving and the performance of competitive masculinity (Hirschon 1992, 2001; Herzfeld 1987, 1992, 2012; Gkintidis 2014, 2018; Papataxiarchis 2016c). The comparison between the two concepts encourages a wider anthropological view that expands beyond anti-austerity movements to embrace the wider value system in Greek society. Such an anthropologically informed analysis is thoroughly accomplished by Katerina Rozakou (2012) in her work on the power and biopolitics of asylum-hospitality in Greece, and the spaces of sociality engendered by solidarity volunteerism in the refugee context (Rozakou 2016a, 2017, 2018a). In relation to "the extravagant generosity of hospitality," she points out, solidarity seems to be a less conspicuous or horizontal alternative (Rozakou 2016b, 190). It is such previous, culturally intimate notions - for example, hospitality - that reconstitute (through opposition) the egalitarianism and political relevance of solidarity.

The post-2010 explosion of solidarity initiatives in Greece has encouraged a reconfiguration of previous attitudes toward giving, something most visible in refugee-crisis volunteerism. Rozakou (2016b, 196-97) wonders whether this interesting transformation has something to do with the nature and short-term needs of refugee aid recipients. At the same time, Rozakou indicates, the newly emerged egalitarian ethos of solidarity that has permeated Greek society under austerity appears to transform the self-identification of middle-class volunteers, leading to a newly relaxed and generous attitude toward asymmetrical giving (Rozakou 2016b). The experience of austerity seems to inspire empathetic perspectives (see Kirtsoglou and Theodossopoulos 2018), encapsulated by the everyday figure of speech, "today it is you, tomorrow it will be me" (Kirtsoglou 2018b). 
It has become increasingly apparent, therefore, that the refugee crisis, combined with the protracted nature of austerity in Greece, has engendered a new dynamic that accentuates previous dilemmas regarding the ethics of solidarity (see also, Cabot 2019; Kirtsoglou 2018a). In what follows, I explore some of these dilemmas, focusing on the narratives of citizens in Patras who had previously shared their views about solidarity with me in a recurring dialogue that has remained open since the beginning of the austerity crisis. Their arguments, taken together, outline a view of solidarity politics during a particular period of Greek political life: the early period of SYRIZA's (The Coalition of the Radical Left) government (winter 2015 to summer 2018).

\section{SOLIDARITY BEYOND POLITICAL COMPROMISE: Views from the Grassroots}

The summer of 2015 proved an unsettling time for Greek politics. The newly elected left-wing SYRIZA government pressed hard for breaching the regime of austerity, imposed by previous governments and the country's lenders (also known as the Troika). ${ }^{10}$ The latter, in an uncompromising mood, defended their programmatic vision of austerity. Unresolved negotiations led to an impasse, the threat of uncontrolled bankruptcy, and capital controls. Many Greek citizens in Patrasand especially those of left-leaning inclination - felt that their country was being punished for resisting austerity. In a referendum that took place early in July 2015, a 61 percent majority voted against the austerity bailout package offered by the Troika. Nevertheless, shortly after the referendum (and under the threat of exiting the EU), the Greek government and its lenders reached a compromise, one that seemed similar to previous austerity memoranda. Subsequently, and following criticisms from its left wing, SYRIZA held elections and was re-elected into power. It seemed that the great majority of SYRIZA's voters considered tactical compromise a necessary political maneuver.

Those among my interlocutors in Patras affiliated with the left felt divided in evaluating such events. Some saw the eventual compromise of the SYRIZA government as a realistic, flexible, and temporary measure that had averted the uncontrolled collapse of the economy and its consequences for the most vulnerable parts of the population. At the same time, other citizens felt betrayed by the pervasiveness of the neoliberal ideas and the extension of austerity. ${ }^{11}$

In the three years following the summer of 2015, I returned to Patras seven times. ${ }^{12}$ During these field trips, I continued my conversations about the ethics of solidarity and the overall conditions of living under austerity, now conceived as a 
continuous, protracted regime. From today's perspective, I can see more clearly that local debates about (a) the country's eventual compromise to one or another regime of austerity, and also (b) previous dilemmas regarding the appropriateness of humanitarian action, followed two parallel ideological trajectories: on the one hand, some Marxist-inspired interlocutors felt compelled to argue in favor of an uncompromising stand, while, on the other hand, several left-inclined solidarians - often more closely affiliated with SYRIZA - accepted compromise as a realistic, temporary, and ultimately subversive tactic. For the latter, compromise was an issue of degree and part of a conscious strategy. It was in fact that degree that separated a "leftist" from a politically conservative position — or at least, this is how the rationalizing author in my mind read their political interpretations. ${ }^{13}$

We can see the rationale of this second - flexible and realistic - position in the words of Eléni, a leading participant in a number of solidarity groups in Patras. She had been one of my gate-openers during fieldwork in 2014-2015, and an inspiring presence in the town's humanitarian scene. It was Eléni who introduced to me to a neighborhood solidarity initiative — closely affiliated with SYRIZA — that provides cooked food for citizens impoverished by austerity. ${ }^{14}$ She has followed the activities of this group consistently since the period of my fieldwork, making addi-

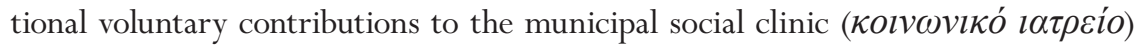

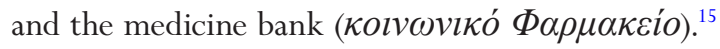

The following conversation took place in May 2016, when we met to catch up, have dinner, and discuss the year that had passed. Early in our conversation, I overwhelmed Eléni with questions about the continuation of austerity and its effect on the motivation and morale of her fellow solidarians. She explained that she, and most solidarians I remembered from the food-distribution initiative, continued their humanitarian involvement, despite austerity-related difficulties in each citizen's own life; and she gave examples of how particular solidarians were "not much better off" than the beneficiaries of the aid they helped provide - yet they stayed connected, in solidarity.

As the discussion moved to an evaluation of the summer of 2015, Eléni confided that a couple of solidarians, mutual friends from the food-distribution initiative, had withdrawn their participation from that particular endeavor, partly because of their disappointment with SYRIZA. Eléni understood their sentiments, considering the earlier strong anti-austerity view of these "ex-comrades," but she stressed that such cases were "exceptions," not the general rule. Everybody was, of course, concerned about the continuation of austerity, which she felt was not the 
fault of SYRIZA, but rather that of the lenders ( $\tau \omega \nu \delta \alpha \nu l \sigma \tau \omega \dot{v})$, who had been "punitive" ( $\varepsilon \kappa \delta \imath \kappa \eta \tau \imath \kappa o i ́)$ in their approach and "inflexible" ( $\alpha \delta \imath \alpha \dot{\lambda} \lambda \lambda \alpha \kappa \tau o \imath)$.

After a short pause, Eléni provided me with a metaphor that embedded the wider politics of Greek debt within the locally meaningful and familiar ethics of solidarity (see graphic below).

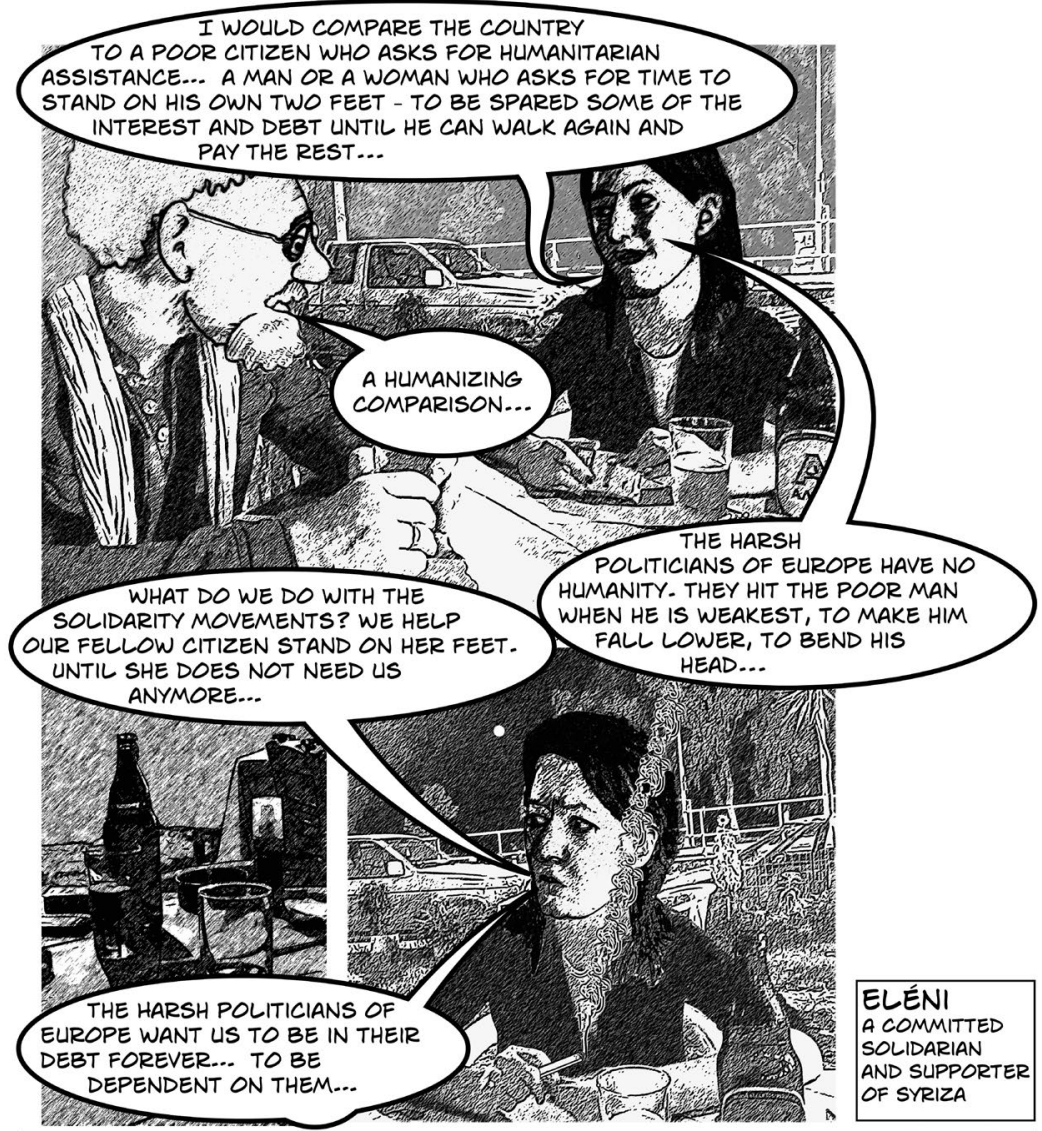

Parergon (b): Let's think for a moment about the unsuspecting ethnographic imponderabilia that are made available through the graphic medium: the image of short- or long-sleeved tops (depending on the time of the day), the illusion of smell (communicated by coffee cups, beer bottles, cigarette smoke), the sensory information (light, heat, or comfort) in the background. This particular evening in May 2016 brought a northerly light breeze and the town seemed quiet. "People need time to return to their normal routines," said Eleni, reflecting on the turmoil of Greek political life a year earlier. She is a medical doctor and runs her own private practice. She had come to meet me after some short volunteering work in the Social Health Clinic. "As you see, I still support the same activities," she said and reached for her cigarettes. 
Eléni's words here prove revealing — not only of the degree to which ideas about humanitarian aid have infiltrated local debates about solidarity but also of informal political views held by several grassroots SYRIZA supporters. They can help us appreciate how the latter reconcile a commitment to the left with the political compromise inherent in local humanitarian action and international politics. In both cases, socialism is perceived as inextricable from giving and forgivingthe cultivation of empathy (see Kirtsoglou and Theodossopoulos 2018; Kirtsoglou 2018 b) and the practice of a less calculative rationality.

Eléni's overall political perspective seemed disarmingly consistent with her practice in the everyday, in particular her humanitarian contributions to the food-distribution solidarity initiative and the social clinic, but also with her concern that beneficiaries not become ensconced ( $v \alpha \beta o \lambda \varepsilon v \tau o v v v)$ in a passive and perpetual state of helplessness. The ideal aid beneficiary for her was epitomized by those citizens who sought — and recognized their need for - help, but who did not become dependent on it. Unlike bourgeois philanthropy that propagates long-term dependency on aid — and Eléni was explicit on this point — solidarity initiatives enable, empower, and raise awareness ( $\varepsilon v \alpha \imath \sigma \theta \eta \tau o \pi o \imath o v ́ v)$. "Well . . . not always," she added, "but that is our goal." Not surprisingly, my rationalizing authorial self celebrated a small victory when I reflected back on Eléni's measured and flexible view of socialism that evening.

It was a short-term victory for that part of my self, lasting only until the following morning, when I met my communist friend Mihális. He is a civil engineer who suffered - as did many other individuals in his profession - from the loss of job contracts during the time of austerity. "A civil engineer is the working-class alternative of an architect," Mihális frequently asserts, but he also admits with disarming honesty that he is not working class. The working class in Patras was almost eradicated in the 1980s, he explains, "when most factories closed down." In his opinion this resulted from competitive international capitalism following Greece's entry into the EU. Such realizations inspired him to become a member of the Communist Party of Greece (KKE), his membership uninterrupted during the past three years.

That morning in May 2016 we sat in the coffeehouse he frequented, and where we had met the previous year. We ordered the usual: a Greek coffee (without sugar, $\sigma \kappa \varepsilon \dot{\tau} \tau o \varsigma \varepsilon \lambda \lambda \eta \nu \imath \kappa o ́ \varsigma)$ for him, and lemonade for me-from a local Patras company, to support the local economy. "As if nothing has changed," I remarked poetically, "same table, same bright Greek morning light." "But everything has changed," he interrupted me, "everything! Greece is now, officially, a compro- 
mised nation." As usual, Mihális spoke with a strong, unequivocating voice, "for the benefit of the customers at the neighboring tables," with most of whom he frequently had heated conversations. This time Mihális wanted to speak without interruptions, and so he did for ten minutes or so, communicating his contempt for the Greek acquiescence to foreign capital, but also his disgust at the EU elite's "colonial attitude."

"Sorry I ranted at you," he said in the end, "I haven't see you since last summer. What are you planning to do in Patras this time? Don't tell me you will go again to these charities [ $\tau \iota \varsigma \varphi \imath \lambda \alpha \nu \theta \rho \omega \pi i \varepsilon \varsigma]$ that you support?” I mumbled a word or two, aware that Mihális saw humanitarian action as a pointless bourgeois undertaking, only to be interrupted one more time. He continued as you can read in the graphic depiction of his monologue (below).

Here again, Mihális, like Eléni, drew metaphorical connections between debt politics at the national level and local humanitarian action, only to arrive at a more pessimistic conclusion: on both levels one could see the same "false" capitalist logic, generating all sorts of compromises, one feeding into the other, clouding the view of the Greek people, including those, he said, affiliated with the "com-

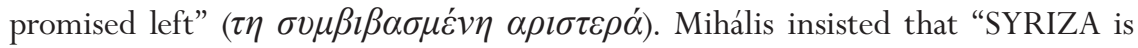
passing ineffectual measures $[\varepsilon \varphi \alpha \rho \mu o ́ \zeta \varepsilon \imath ~ \eta \mu і \mu \varepsilon \tau \rho \alpha]$." A real, permanent solution, he concluded, had to involve a drastic rift, a total restart for the Greek economy and society, whatever the cost for the ordinary citizen.

I have learned over the years to anticipate Mihális's conclusions, which mostly align with that of the Communist Party. The trajectories of his arguments, however, often surprise me, and for the most part compel me to agree, as they point out, relentlessly, that local and national politics are ridden by ineffectual measures and cover-ups. The zest and enthusiasm of his voice awakens the Marxist spirit within me, which calls attention to the deceptive work of rationalizations in interpreting political events and local practices, such as my own previous participation in humanitarian initiatives. Was such participation a misguided expression of my bourgeois guilt? Or do I sugarcoat my philanthropic tendencies with the radical rhetoric of solidarity?

The softer Marxist voice in my mind strives for additional explanations. He questions the ability of Mihális to evoke uncompromising idealism within me. This could be guilt for my own failed commitment to a disciplined communist trajectory, something Mihális understands and easily exploits. The particular conversational context may also further heighten Mihális's persuasiveness: the commensal and egalitarian context of male solidarity (see Papataxiarchis 1991, 1999) into 


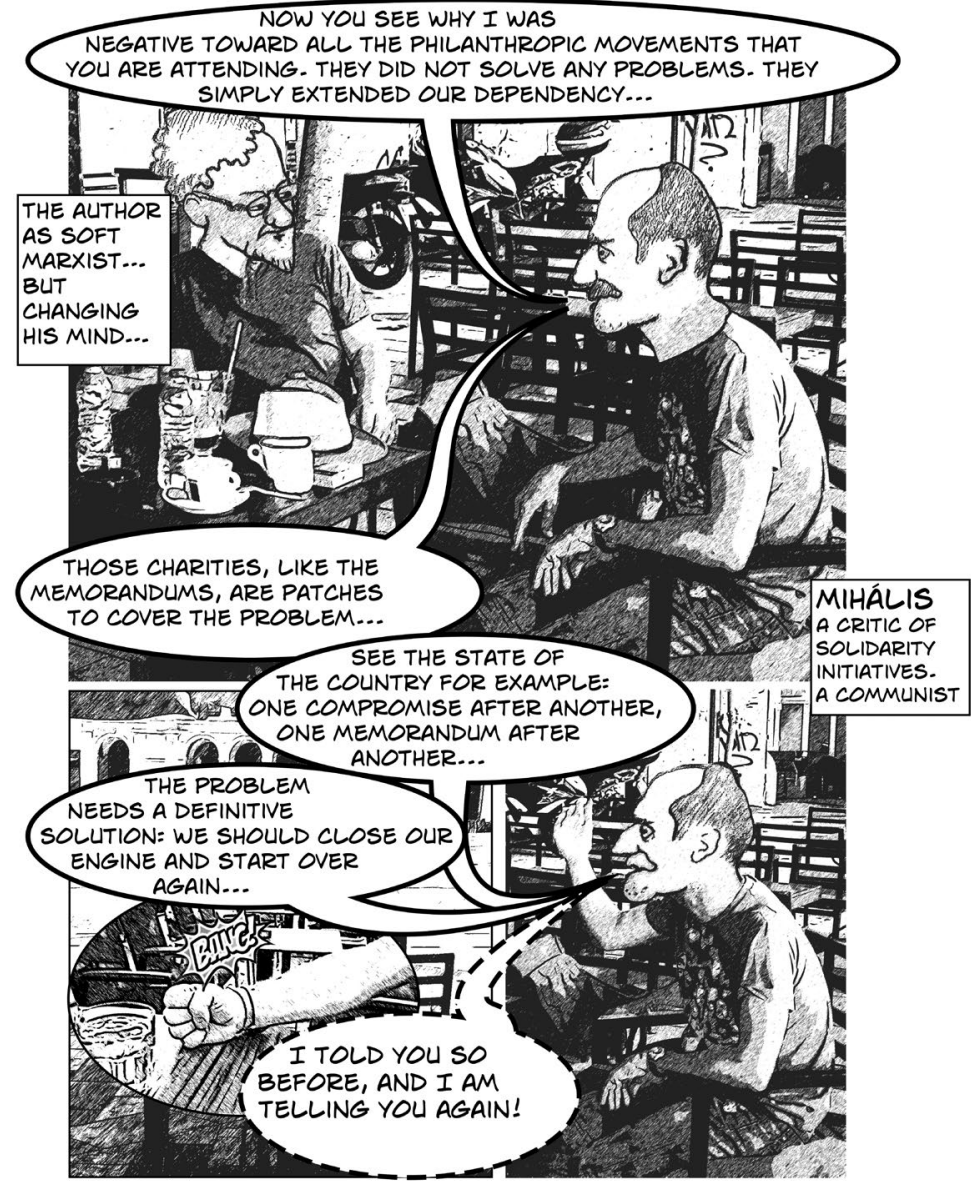

Parergon (c): Graphic ethnography opens a window onto the sites of anthropological research. Coffeehouses and cafeterias have been emblematic contexts of anthropological research in Greece. The panels that follow provide glimpses of the cafeteria. Here we see Mihalis feeling at home in the coffeehouse; as his relaxed body posture indicates. He is also at home ideologically, not only because this particular establishment attracts leftinclined customers, but in a broader sense: the expressive culture of the coffeehouse promotes disinterested sociality, generating the perfect context for criticizing local, national, and international hierarchies (Papataxiarchis 1991, 1999; see also Herzfeld 1985). More recently, foreigners have criticized the austerity-afflicted Greeks for spending too much time in the coffeehouse (see Knight 2015). They have failed to see-in their orientalizing critique-the humanizing cultural principles that constitute socialization in the coffeehouse as an act of resistance to neolibeal individualism (see Sutton 2016).

which, as a Greek man, I have tried to fit, albeit rather uncomfortably. In his now classic analysis, Michael Herzfeld (1985) has exposed the performative and competitive aspects of Greek masculinity; these Mihális masterfully commands and I - a Greek academic living abroad - have idealized and awkwardly imitated. The truth is that I have always felt more comfortable talking with female respondents. 
Another friend and colleague who knows Mihális very well is Georgía. Both were once members of the Communist Party, although now Georgía supports SYRIZA. She has invited Mihális to participate many times in a wide array of humanitarian initiatives, but Mihális has always refused. "It doesn't have to do with party loyalty," Georgía clarified in a subsequent conversation with me: "I have invited him to help with actions $[\delta \rho \alpha \dot{\sigma} \varepsilon l \varsigma]$ that are not tainted by political parties." "His refusal," Georgía further explained, "is perhaps ideological as much as it is cruel $[\sigma \kappa \lambda \eta \rho \eta ́]$.” This idea provided Georgía with the impetus to summarize her own views about the ethics of solidarity, aided by her fellow solidarians Maria and Tasia (see graphic below), with whom I had previously spent several hours working in the same food-distribution initiative in which Eléni participates.

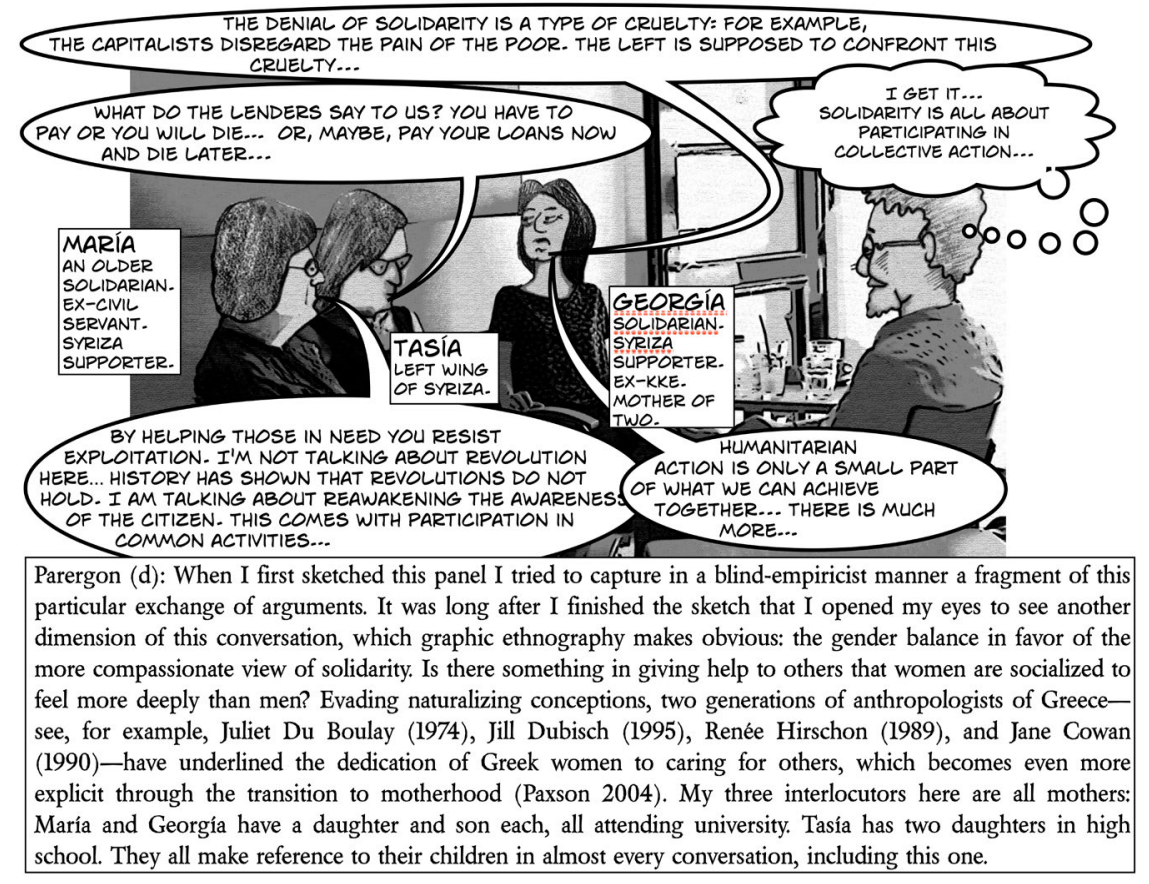

The vision of solidarity shared between Georgía, Maria, and Tasia conveys an empowering socialist message based on the immediacy of practical action. And it is here that Mihális's rejection of humanitarian action, however persuasive at the ideological level, fails to meet the immediate priorities of local society and the expectation that the left is - or should be-better than the predominant neoliberal politics it seeks to replace. This is pointed out explicitly by Mihális's friends, such as Georgía, who are well versed in the Marxist critique of humanitarianism but 
choose to invest heavily in solidarity initiatives. Much to the pleasure of my rationalizing self, Georgía and her fellow solidarians provided me with the following explanation that outlines a long-term vision of persistent, indirect resistance (see graphic below).

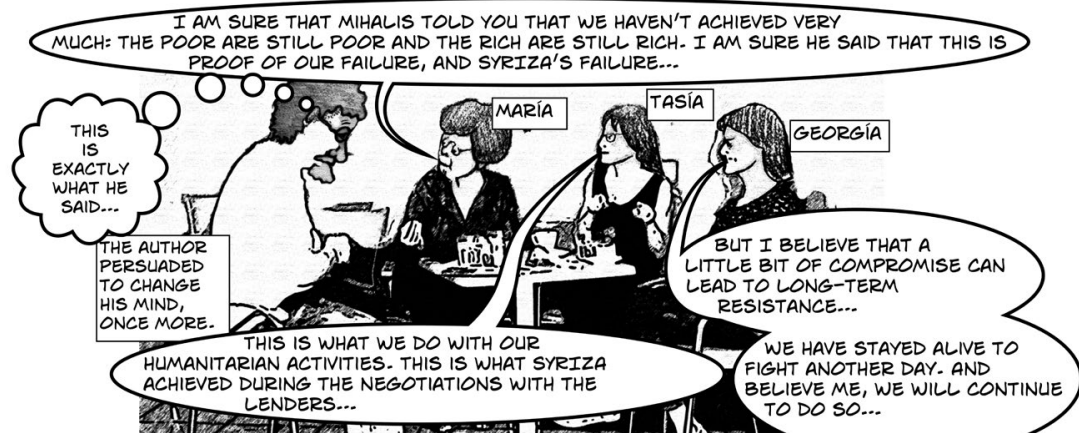

Parergon (e): Once more, the graphic medium invites some commentary on the gender composition of this conversation. The male ethnographer dressed in performative simplicity is somewhat static and politely reserved in all female company, as customary of the middle class. "You remind me of Tsakalotos" (the minister of finance), said Maria to the author, "your cultured look and the glasses"-which the latter took as a compliment. Similarly, María, Georgía, and Tasía's dress code is at peace with their age. "Is it polite to reveal a woman's age?" I asked when I showed them my sketches. "Why use words," said Maria, "people can tell by looking at the picture." She stands in the frame of the sketch with her legs closer together-in modesty-but her hands point toward her arguments dynamically. Georgía and Tasía, cross-legged and somewhat more relaxed, convey the confidence of a slightly younger generation: they are feminists and support the left, but not in "a hysterical manner," they underline. Their confidence reminds us that we have come a long way since the gender politics of the 1970s and 1980s, when women's inclusion in public spaces such as cafeterias was contested, as Jane Cowan (1990, 1991) has beautifully portrayed in her earlier work. Twenty years later, Greek women are much more visible in public life, having taken leadership roles-not merely in solidarity initiativesbut in most political parties or movements. Yet, echoing Sherry Ortner (2015), all women in this graphic agree that the project of feminism is far from over; "lots needs to be achieved," Georgía emphasized in a previous conversation.

Thinking with hindsight about this conversation, my soft-Marxist authorial self recollects my sense of ease in the company of this group of women. Their female company emanated a relaxed sense of trust, ${ }^{16}$ solidified through the previous experience of working together in the food-distribution initiative. This contrasted the fervent discussions with Michális at the coffeehouse, during which we pushed political ideas to their logical extremes. The contrast between the conversational contexts in this section encourages me to admit that my authorial split is also partly constituted by sharing different types of gendered solidarity, as well as the unique combination of the gendered-cum-ideological makeup of each conversational company of friends.

\section{CRITICAL AMBIVALENCE AND COMPLEXITY}

Aware that a certain degree of compromise is inherent in resistance, my rationalizing authorial self is persuaded by the argument of my solidarian interlocutors in Patras: solidarity initiatives in austerity-ridden Greece-despite their partial complicity with an imperfect and unequal social system-have an empow- 
ering dimension: they engender political radicalization (Rakopoulos 2016; Rozakou 2018b) and opportunities to demonstrate a certain political responsiveness (Cabot 2014; Athanasiou and Alexandrakis 2016; Theodossopoulos 2016b; Rozakou 2018b). As my respondents Eléni and Georgía underline, it is better to get involved and resist austerity through action than to stay passive and allow the pessimism of austerity to overtake you. Through solidarity activities, Eléni argues, "one may also help a fellow citizen or two, but that is not the only purpose."

My uncompromising authorial self is not fully persuaded by such an enticing but indirect radical vision. He believes that indirect resistance, for example, as framed by James C. Scott $(1985,1990)$, does not remain uncontaminated by hegemony (see Gledhill 1994, 2012; Roseberry 1994; Theodossopoulos 2015). Informal solidarity initiatives at the local level — to the degree that these provide a resisting alternative to austerity - are not autonomous from power, or, at the very least, not autonomous enough. They may indeed provide a temporary respite for the subaltern - in this case, the victims of austerity - but they also allow hegemony to adapt to (and neutralize ideologically) any small-scale challenges that arise.

Mihális succinctly encapsulated this argument in a subsequent conversation: "With the battle of delays, it is not only the weak who take respite, but also the powerful!"17 Indirect resistance and strategic compromises, according to this point of view, detract attention from and postpone the battle against enduring inequality. Solidarity initiatives at the local level, or reliance on installments of financial aid at the national level, extend and reproduce dependency. According to this logic, humanitarian solidarity provides yet another rationalization - or veridiction, that is, "the reason and reasoning" (Faubion 2019, 2) —of established regulatory biopolitics, a perspective that leads us into seeing volunteerism as an ideological cover-up of neoliberalism (cf. Muehlebach 2012).

My two authorial selves have served so far as representational devices to summarize this disagreement, but also, more important, to highlight that both views can trouble the very same individuals. While my soft-Marxist self rationalizes the imperfections of solidarity (seen as indirect resistance), my hard-Marxist self condemns with pathologizing certainty the implication of solidarity with hegemony - "here is another version of false consciousness," he says, "and I can see it." Exhausted from the ceaseless wavering between those two positions, I am now prepared to admit that both coexist at the local context of humanitarian solidarity. They inspire particular solidarians, and in some cases, they represent ideological attachments in different periods of one's life, such as in the case of Georgía, who 
once supported the Communist Party of Greece (KKE) but now follows the more flexible position (regarding solidarity) espoused by SYRIZA.

Very much like my two authorial personas, those among my interlocutors in Patras who are concerned about the ethics of solidarity are not neatly divided along the arguments they articulate in the heat of a conversation. In other moments - for example, while reflecting on particular practices or unanticipated problems - they appear disarmingly open to examine new arguments or to embark on self-evaluating reflection. Eléni has repeatedly underlined, for example, that "solidarity issues are not, not in the least, closed . . . every case is different." 18 Ideological positions are also important and necessary, she adds, but this is "food

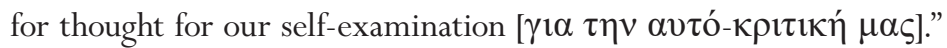

Georgía, Tasia, and Maria similarly agree that immediate humanitarian action comes before ideology. But they all hold slightly different positions with respect to the efficacy of solidarity, despite their left-leaning inclinations and support for the same party. Maria has a hard time forgiving Mihális for his inaction, while Tasia agrees with several of his critical arguments_- "but only at the ideological level," she clarified, "not in practice." Georgía admitted that she feels "tortured" by her Marxist background, yet found this struggle productive. "When I see Mihális," she

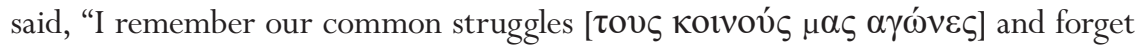
our disagreements." Mihális explicitly mentioned that he treasures the "common

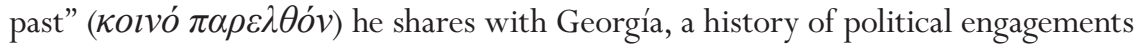
that made him, he adds, the person he is now.

In August 2018, I showed Eléni and Mihális the graphic panels that support this article. Eléni told me that she recognized the position of feeling split in two, especially when troubled by solidarity dilemmas. For example, "to help or not to help this particular human being, and to what degree?" Mihális revealed that he has not always been programmatically "harsh" ( $\sigma \kappa \lambda \eta \rho o ́ \varsigma)$ —in fact, he mentioned participating in solidarity activities too! I recaptured their reflections in graphic form (below).

We may consider Eléni's and Mihális's simultaneity of views indicative of intersubjective ambiguity (Jackson 1998): undoubtedly, their parallel and partially overlapping identifications result from their relationships with others. Eléni explains that the views of other solidarians - whom she respects - generate ethical questions in her mind, for example, about the purpose of solidarity. Yet her relationship with the recipients of aid, she argues, provide her with all the necessary “answers.” Mihális sees as his important interlocutors his comrades in the Communist Party of Greece (KKE) — with whom he talks about ideology and practice. 

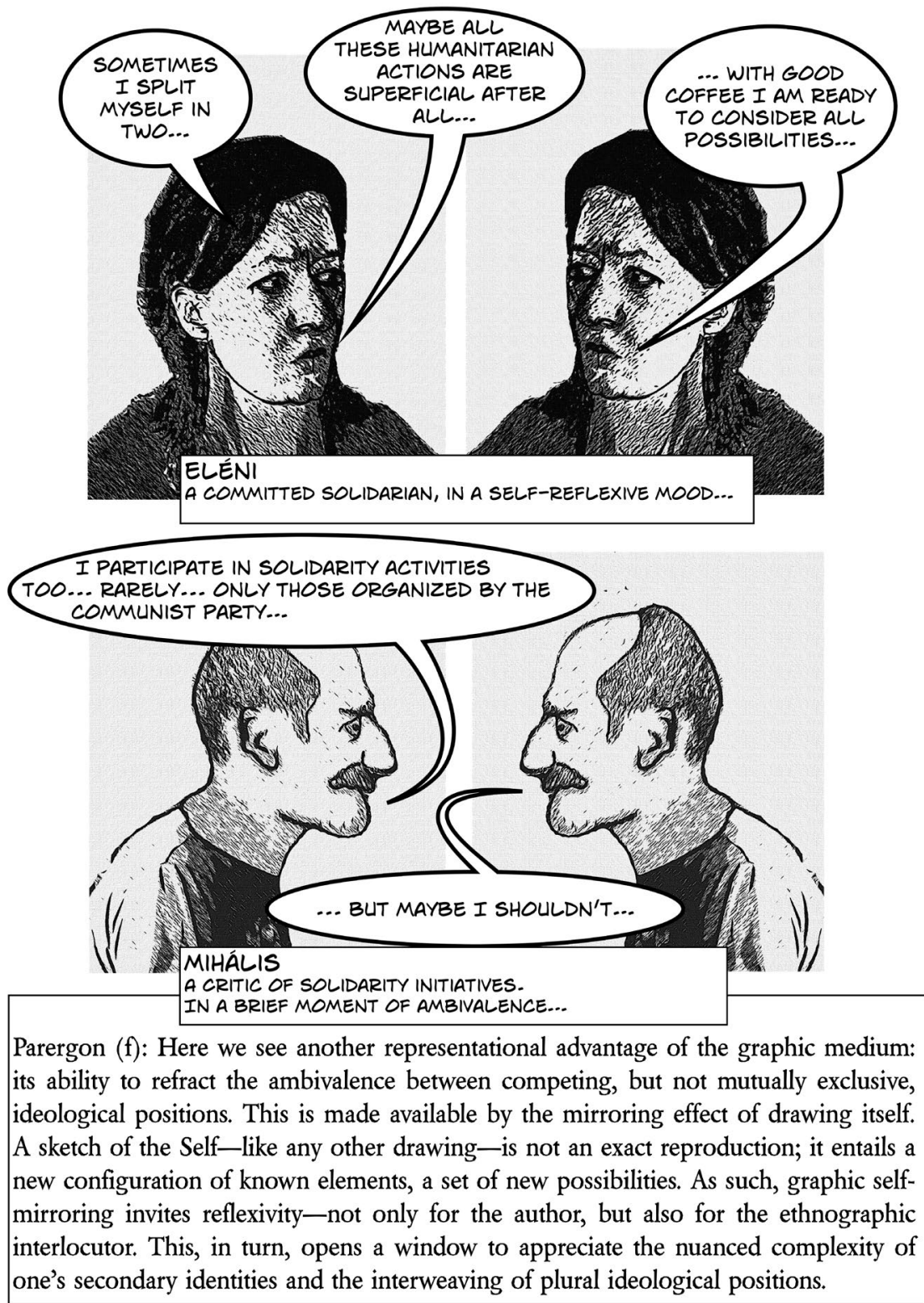

He hates ambiguity, he admitted, but recognizes himself in my mirroring sketch. Eléni's and Mihális's mirroring reflections invited me to bring my ethnographic narrative to a close, as I have reached a point anticipated much earlier in this article: their relational self-positioning mirrors my authorial split, which was constituted in dialogue with them. 


\section{THE CYCLICALITY OF RESISTANCE AND COMPROMISE}

Does humanitarian solidarity generate a certain degree of emancipatory resistance to neoliberal austerity, or does it reproduce dependency on aid, which leads to yet another compromise with hegemony? In my attempts to address how solidarians in Patras respond to this irresolvable question - a true aporia - I made visible how I opened myself to parallel, contrasting, but partly overlapping views in the field, as well as to the persuasiveness of such views. I experimented with representational devices - the split of the authorial voice, graphic ethnography, parerga - that capture the open-ended nature of the original dilemma, in an attempt to escape from singular answers constituting one or another "one-dimensional sort of explanation" (Williams 1979, 144). Ethnography is intimately implicated in the political ramifications of the ethnographic process, which invites us to acknowledge the simultaneity and interweaving of parallel arguments in local narratives and interpretations. Some of these unofficial political views may encompass concepts studied by traditional anthropology-for example, in the case I examined here: time, gift giving, and hospitality. Local views of temporality, for example, often become transformed in times of crisis (Knight and Stewart 2016; see also, Knight 2012, 2015a; Hirschon 2013). An over-burdensome (and austerity-afflicted) perception of present-ness (Bryant 2016) can lead to an overstretched temporariness, extending dependency — a view favored by many solidarians and my rationalizing self. Yet in the narratives of those favoring a harder Marxist view, dependency on aid has been drawn out too far; it is now seen as embedded within an all-embracing hegemony. Solidarity can therefore not fully redeem dependency on aid.

My left-leaning interlocutors in Patras seem perfectly aware of and troubled by the asymmetrical nature of giving (cf. Rozakou 2012, 2016b, 2018a; Cabot 2016). This awareness leads them to debate, adopt, or criticize, as well as - as Rozakou testifies with respect to a variety of volunteerism initiatives - minimize over time their inhibition regarding unreciprocated gift giving (Rozakou 2018b). Herzfeld reminds us that offering mutual assistance does not constitute a foreign concept in Greek society; it can solidify a common stance "against potentially hostile others" (Herzfeld 2016, 202), including domestic and foreign proponents of austerity. It represents a culturally intimate response (or responsiveness) to the facelessness of bureaucracy (Herzfeld 1992, 1997), the official politics of hospitality (Papataxiarchis 2006; Rozakou 2012), established inequalities, exploitation, and competitive individualism (Athanasiou and Alexandrakis 2016). The success of solidarity as a bridge concept (Rakopoulos 2016) relies on this emphasis on disin- 
terested sociality and reciprocity (Papataxiarchis 2018; Rakopoulos 2018; Rozakou 2018b).

My rationalizing authorial self appears most content with drawing such anthropological interpretative links, but my uncompromising Marxist self views this intellectual project with wariness, and he wonders: Is this the purpose of anthropology? Or is such dependence on cultural values (or concepts) an ideological justification of an imperfect, unequal social reality - another rationalization? My rationalizing self respectfully welcomes this classic Marxist perspective and responds with a postrationalization: even if we reduce culture to ideology, what better way to rid ourselves from its all-embracing mystification than to interpret, analyze, and understand its treacherous logic? Maybe this type of anthropological struggle can prove useful after all, in the long term, as much as the critique that prompted it in the first place.

It is at this precise point - the demystification of the wonder we call culture - that my two internalized voices declare a temporary truce. They both agree with the initial Foucauldian proposition that structured this article: that resistance is never inexhaustible or complete. Resisting subjects are implicated with the wider nexus of power that surrounds them, even with the very power structures they try to resist. Which leads us to acknowledge that resistance is not autonomous from the broader cultural and politico-economic relationships that trigger it in the first place (Keesing 1992; Gledhill 1994, 2012; Ortner 1995; Theodossopoulos 2015).

Fighting against protracted austerity requires a conscious, long-term strategy of resistance, which can be seen here as a flexible inventive tactic (Herzfeld 2016). Short-term compromises - in the field of humanitarian solidarity, for examplemay lead to the defeat of the pervasive temporariness structured by austerity, but they may also provide temporary solutions to immediate problems, constituting a form of pragmatism that has a generative effect (Papataxiarchis 2018, 230-3; see also Rakopoulos 2014a, 2018). In such pragmatic terms, solidarity initiatives in crisis-afflicted Greece make a contribution greater than (and not reducible to) the heterogenous partial interests and partial commitments of their membership: collective action here generates unique and unpredictable outcomes and relationships (Alexandrakis 2016, 7-8; Athanasiou and Alexandrakis 2016, 260), what Evthymios Papataxiarchis $(2018,245)$ calls "the un-envisioned effects of praxis."

Nevertheless, the unpredictable, transformative benefits of solidarity in practice do not preclude a self-critical stance. On this point all the protagonists of this article agree. A sharper, uncompromising reevaluation of the pragmatic logic engendered by solidarity can serve as a critical lens against the rationaliz- 
ing work of hegemony. In this respect, the interventions of my uncompromising-cum-pathologizing self serve as a metacognitive filter, a second layer of critical thinking about previous thinking, which constitutes a prerequisite for a reflexive

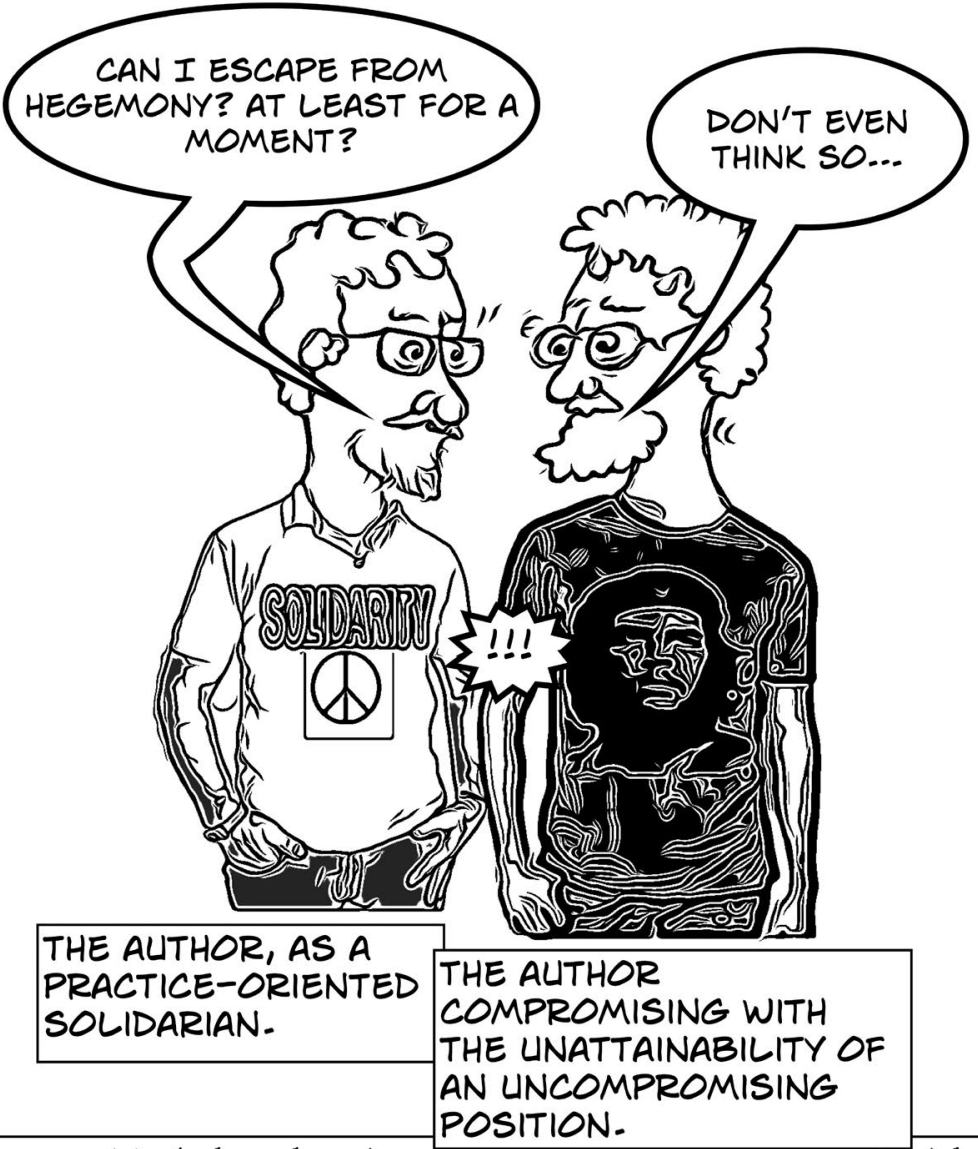

Parergon (e): At last, there is some peace between my two authorial voices: a productive complicity so to speak. Unhappy with their strategic compromises, they prepare with pragmatism for what comes tomorrow. They collaborated, while arguing with each other, to portray the ambivalence of solidarity ethics, but more importantly to present some opportunities for ethnographic practice. These involve splitting the authorial self and graphic ethnography, which I combined here to unsettle self-knowledge. What we think we know is a collaborative project that involves several authors. In ethnographic writing most important are the people we call "our interlocutors." Their voices are often part of the ethnographer's voice. 
Marxist approach: the uncovering of biases - bourgeois, interpretative, analytical, authorial - that lead us to see our interpretations as closed or "finished products" (Williams 1977, 128). Seen from this perspective, the two arguments about solidarity that have troubled my respondents in Patras are mutually and productively constituted, for they are set against each other-one engendering the other in a codependent relationship. Self-critique — such as the auto-ethnographic split I introduced and depicted in graphic form in this article - offers a compass for navigating through the compromises inherent in both theory and practice.

\title{
POSTSCRIPT
}

In July 2019, on a short trip to vote in the Greek general elections, ${ }^{19}$ I ran into Eléni and Georgía at a café in St. Georgiou's Square, the very center of Patras. After sharing our disappointment about the defeat of the left, the discussion drifted to the particular food-distribution initiative at which we had all worked in previous years. "We will continue,” said Georgía, “we need to keep our spirit high, not only for those in need, but also for ourselves." "Now that the right wing is in power, it is more important to meet regularly," added Eléni, "to remember what we have in common." Her words echoed in my ears two days later, when I called Mihális on the phone. Now that political power has shifted away from the left, more common ground exists between him, Eléni, and Georgía: new critical trajectories, parallel arguments, but also lessons from the past. There is also more scope for productive compromise between my rationalizing and pathologizing selves.

\begin{abstract}
This article introduces an autobiographical analytical tool that aims to elucidate the complexity and interweaving of opposing ideological positions as these emerge in the field and while writing ethnography. The technique introduced makes visible the split of the author's identity into two: between that of a hard and a soft Marxist, where each authorial self resonates with a particular local perspective. The split and those who have stimulated it - the real-life protagonists in the field-become reanimated and embodied through the self-mirroring representational lens of graphic ethnography. Overall, the article provides an experimental exercise in reflexive Marxist anthropology, which, apart from ethnographic innovation, engages with the ambivalence and codependence of competing arguments about the ethics of humanitarian solidarity in austerity-afflicted Greece. The essay suggests that local arguments about solidarity are coconstituted through pragmatism and productive self-critique in times of protracted austerity. [auto-biographical split; graphic ethnography; solidarity; indirect resistance; reflexive Marxism; Greece]
\end{abstract}




\section{Пері́ $\eta \psi \eta$}

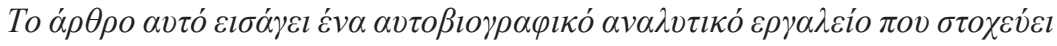

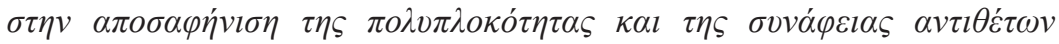

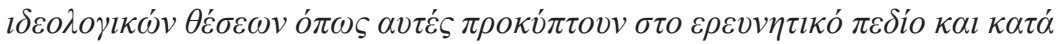

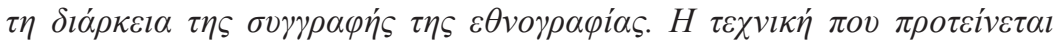

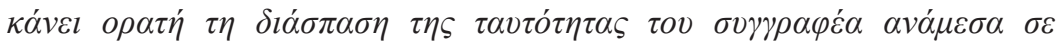

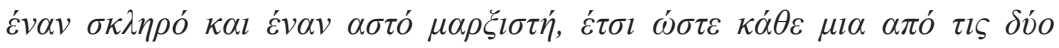

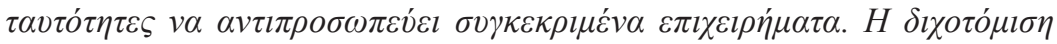

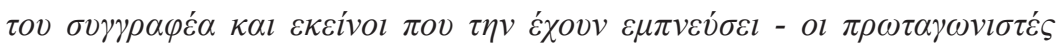

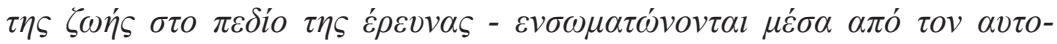

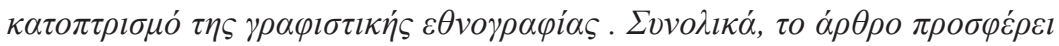

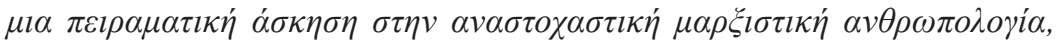

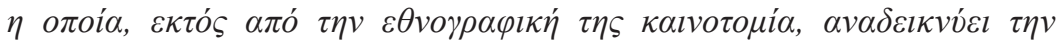

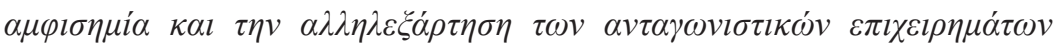

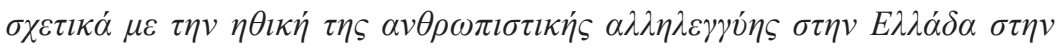

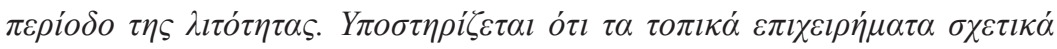

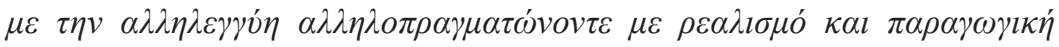

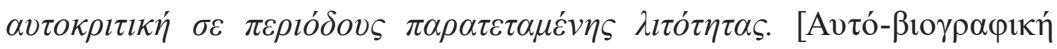

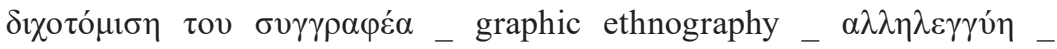

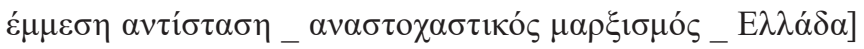

\section{NOTES}

Acknowledgments I would like to thank my ethnographic protagonists-Eléni, Georgía, María, Tasía, and Mihális - for inspiring and shaping the writing of this article, as well as all other solidarians in Patras who shared their views with me in 2014-2016. I also thank the anonymous reviewers and editors of Cultural Anthropology, in particular, Heather Paxson. Their comments and close engagement with the article helped me develop its representational innovation in a direction that may benefit the wider anthropological field. The research on which this work was based was supported by UK's Economic and Social Research Council (ESRC, research grant ES/L005883/1). I have a secondary affiliation with the Smithsonian Tropical Research Institute, Panama.

1. Over the past decade, the growth of humanitarian solidarity initiatives in Greece has inspired a number of anthropological responses, which I use here as a conceptual repository to contextualize my auto-ethnographical reflections and the positions of my interlocutors in the field (see Bakalaki 2008; Cabot 2014, 2016, 2019; Rakopoulos 2014a, 2014b, 2015a, 2015b, 2016, 2018; Herzfeld 2016; Papataxiarchis 2016c, 2018; Rozakou 2016a, 2016b, 2017, 2018a, 2018b; Theodossopoulos 2016b). This recent literature about solidarity in Greece has been, in turn, informed by wider anthropological contributions that reflect on and redress the wider ideological asymmetries between aid providers and recipients (de Waal 1997; Fassin 2007, 2011; Fassin and Pandolfi 2010; Bornstein and Redfield 2011; Muehlebach 2012; Redfield 2012; Ticktin 2014).

2. In the anthropology of Greece, we have seen previous experiments that depart from conventional representational norms. Most notably among these are the ethnographies of James D. Faubion (1993) and Neni Panourgiá (1995). Jane K. Cowan $(1990,1991)$ has experimented with setting voices apart to represent variable positions taken by women and men with respect to hegemonic gender notions. 
3. Patras is the capital of Peloponnese, an urban center in southwestern Greece, a threehour drive from Athens. It is the third-largest city in the country, with about 210,000 inhabitants. It is not a tourist destination, although tourists use its port, which connects Greece with Italy. The local economy — which relies on services and commerce - was harshly affected by the introduction of austerity measures in 2010. Patras has been for me the site of ongoing fieldwork for longer than two decades, including a four-year-long project (2014-2018) that focused on the consequences of austerity in Greece.

4. It includes full-length, graphic monographs (Hamdy and Nye 2017) or graphic articles (Theodossopoulos 2019), analyses combining text and graphic components (Schwanhäußer 2016; Theodossopoulos 2016b), book reviews (Theodossopoulos 2017), short graphic panels (Shah 2017), or emulations of political cartooning (Theodossopoulos forthcoming).

5. These are the Communist Party of Greece (KKE) and SYRIZA (the Coalition of the Radical Left); the latter was, at the time of writing, the political party in power. My analysis does not claim to address the formal positions of these two parties toward solidarity; rather, it discusses local, unofficial adaptations of these views and dilemmas about solidarity in Patras.

6. In addition to the solidarity-specific literature, I draw insights from anthropological interventions that examine solidarity in the context of the recent migration and refugee crisis (Papataxiarchis 2016a, 2016b; Green 2018; Kirtsoglou 2018b); the temporality of the crisis (Knight 2012, 2015a; Knight and Stewart 2016); and the transformative dimensions of anti-austerity resistance (Alexandrakis 2016; Athanasiou and Alexandrakis 2016; Poulimenakos and Dalakoglou 2018).

7. See also Haskell 1985a, 1985b; Cunningham and Innes 1998; Fassin 2012; Trundle 2014; Osella, Stirrat, and Widger 2015.

8. See Rakopoulos 2014a, 2014b, 2015a, 2015b, 2018; for more cases of alternative food distribution see, Sutton et al. 2013; Knight 2015b; Douzina-Bakalaki 2017; Agelopoulos 2018.

9. See also Bakalaki 2008; Cabot 2014, 2016; Rozakou 2016a, 2016b.

10. The European Commission (EC), the International Monetary Fund (IMF), and the European Central Bank (ECB).

11. For example, communists, anarchists, and the far-left wing of SYRIZA.

12. To carry out fieldwork as part of the ESRC grant "Household Survival in Crisis," which focused on the consequences of austerity for Greek families. I conducted the main fieldwork for this project from August 2014 to August 2015. The follow-up field trips (2015-2018) provided additional data and an opportunity to test my earlier conclusions as subsequent events unfolded.

13. Neni Panourgiá (2009, 15-16) has highlighted the difficulty with defining the term left-

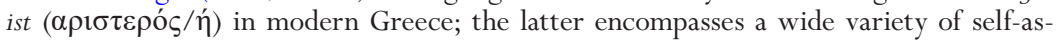
criptions and ideological positions. The same applies to the equally contested category the Greek left ( $\eta \alpha \rho ı \sigma \tau \varepsilon \rho \alpha$ ), which is, nevertheless, used rather inclusively in local contexts to include bourgeois-socialism.

14. For an ethnographic description of the particular initiative, see Theodossopoulos 2016b.

15. Between 2013 and 2016, her participation in solidarity activities took about seven hours a week, divided into different initiatives. In 2016, after the medicine bank closed down, she reduced her volunteering services by half to devote more time to her dermatological practice and her daughter. In the meantime, the social clinic has reduced its opening hours to one day a week (Thursdays); Eléni now serves in the latter once every two weeks.

16. The Greek notion of a company of friends (parea) has been explored by several anthropologists who analyzed the social and gendered dynamics between people socializing regularly together. For all-male pareas, see Papataxiarchis (1991); for female or mixed-gender pareas, see Cowan (1990) and Kirtsoglou (2004).

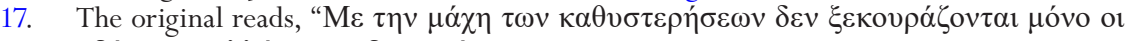

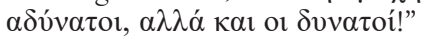




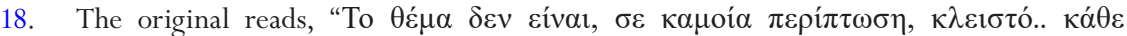

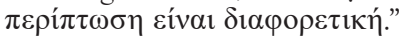

19. The Greek general elections of July 7, 2019, brought into power the conservative party, Nea Democratia. It remains to be seen if the numerous solidarity initiatives - and the overall solidarity ethos — which thrived during the government of SYRIZA, will endure. My prediction is that several solidarity initiatives will continue to function as radicalized loci of indirect resistance, raising social awareness against the consequences of austerity and the competitive spirit of neoliberal politics.

\section{REFERENCES}

Abu-Lughod, Lila

1990 "The Romance of Resistance: Tracing Transformations of Power through Bedouin Women." American Ethnologist 17, no. 1: 41-55. https://doi.org/10.1525/ ae.1990.17.1.02a00030.

Agelopoulos, Georgios

2018 "Put the Blame on Potatoes: Power Relations and the Trajectories of Goods during the Greek Crisis." In Critical Times in Greece: Anthropological Engagements with the Crisis, edited by Dimitris Dalakoglou and Georgios Agelopoulos, 217-25. London: Routledge.

Alexandrakis, Othon

2016 "Introduction: Resistance Reconsidered." In Impulse to Act: A New Anthropology of Resistance and Social Justice, edited by Othon Alexandrakis, 1-15. Bloomington: Indiana University Press.

Athanasiou, Athená, and Othon Alexandrakis

2016 "Conclusion: On an Emergent Politics and Ethics of Resistance." In Impulse to Act: A New Anthropology of Resistance and Social Justice, edited by Othon Alexandrakis, 246-62. Bloomington: Indiana University Press.

Bakalaki, Alexandra

2008 "On the Ambiguities of Altruism and the Domestication of Emotions." Historein 8: 83-93. http://dx.doi.org/10.12681/historein.40.

Bochner, Arthur P., and Carolyn Ellis

2016 Evocative Autoethnography: Writing Lives and Telling Stories. New York: Routledge. Bornstein, Erica, and Peter Redfield

2011 "An Introduction to the Anthropology of Humanitarianism." In Forces of Compassion: Humanitarianism between Ethics and Politics, edited by Erica Bornstein and Peter Redfield, 3-30. Santa Fe, N.Mex.: School for Advanced Research Press.

Bryant, Rebecca

2016 "On Critical Times: Return, Repetition, and the Uncanny Present." History and Cabot, Heath Anthropology 27, no. 1: 19-31. https://doi.org/10.1080/02757206.2015.1114481.

2013 "The Social Aesthetics of Eligibility: NGO Aid and Indeterminacy in the Greek Asylum Process.” American Ethnologist 40, no. 3: 452-66. https://doi.org/10.1111/ amet.12032.

2014 On the Doorstep of Europe: Asylum and Citizenship in Greece. Philadelphia: University of Pennsylvania Press.

2016 “'Contagious' Solidarity: Reconfiguring Care and Citizenship in Greece's Social Clinics." Social Anthropology 24, no. 2: 152-66. https://doi.org/10.1111/14698676.12297.

2019 “The European Refugee Crisis and Humanitarian Citizenship in Greece." Ethnos 84, no. 5: 747-71. https://doi.org/10.1080/00141844.2018.1529693.

Clifford, James, and George E. Marcus, eds.

1986 Writing Culture: The Poetics and Politics of Ethnography. Berkeley: University of California Press. 
Collins, Peter, and Anselma Gallinat

2010 "The Ethnographic Self as Resource: An Introduction." In The Ethnographic Self as Resource: Writing Memory and Experience into Ethnography, edited by Peter Collins

Cowan, Jane K. and Anselma Gallinat, 1-22. New York: Berghahn.

1990 Dance and the Body Politic in Northern Greece. Princeton, N.J.: Princeton University Press.

1991 "Going Out for Coffee? Contesting the Grounds of Gendered Pleasures in Everyday Sociability." In Contested Identities: Gender and Kinship in Modern Greece, edited by Peter Loizos and Evthymios Papataxiarchis, 180-202. Princeton, N.J.: Princeton University Press.

Cunningham, Hugh, and Joanna Innes, eds.

1998 Charity, Philanthropy and Reform from the 1690s to 1850. Basingstoke, UK: Palgrave Macmillan.

Davies, Charlotte Aull

1998 Reflexive Ethnography: A Guide to Researching Selves and Others. London: Routledge. de Waal, Alex

1997 Famine Crimes: Politics and the Disaster Relief Industry in Africa. Oxford: James Currey.

Douzina-Bakalaki, Phaedra

2017 "Volunteering Mothers: Engaging the Crisis in a Soup Kitchen of Northern Greece.” Anthropology Matters 17, no. 1. https://www.anthropologymatters.com/ index.php/anth_matters/article/view/480/605.

du Boulay, Juliet

1974 Portrait of a Greek Mountain Village. Oxford: Clarendon Press.

Dubisch, Jill

1995 In a Different Place: Pilgrimage, Gender, and Politics of a Greek Island Shrine. Princeton,

Fabian, Johannes N.J.: Princeton University Press.

1983 Time and the Other: How Anthropology Makes Its Object. New York: Columbia University Press.

Fassin, Didier

2007 "Humanitarianism as a Politics of Life." Public Culture 19, no. 3: 499-520. https:// doi.org/10.1215/08992363-2007-007.

2011 Humanitarian Reason: A Moral History of the Present. Berkeley: University of California Press.

Fassin, Didier, ed.

2012 A Companion to Moral Anthropology. Oxford: Wiley-Blackwell.

Fassin, Didier, and Mariella Pandolfi

2010 "Introduction: Military and Humanitarian Government in the Age of Intervention." In Contemporary States of Emergency: The Politics of Military and Humanitarian Interventions, edited by Didier Fassin and Mariella Pandolfi, 9-25. New York: Zone.

Faubion, James D.

1993 Modern Greek Lessons: A Primer in Historical Constructivism. Princeton, N.J.: Princeton University Press.

2019 “On Parabiopolitical Reason.” Anthropological Theory 19, no. 2: 219-37. https://doi.

Foucault, Michel org/10.1177\%2F1463499618770558.

1978 The History of Sexuality, Vol. 1: The Will to Knowledge. London: Penguin.

Geertz, Clifford

1989 Works and Lives: The Anthropologist as Author. Cambridge: Polity Press.

Gkintidis, Dimitrios

2014 "On European Money in Greece: Anthropological and Political Perspectives." Occasional Paper no. 1/14, SEESOX, St. Antony's College, University of Oxford. 
2018 "Free Money, Spoiled Recipients: The Capitalist Crisis as a Moral Question among Greek Technocrats.” In Critical Times in Greece: Anthropological Engagements with the Crisis, edited by Dimitris Dalakoglou and Georgios Agelopoulos, 32-44. London:

Gledhill, John Routledge.

1994 Power and Its Disguises: Anthropological Perspectives on Politics. London: Pluto.

2012 "Introduction: A Case for Rethinking Resistance." In New Approaches to Resistance in Brazil and Mexico, edited by John Gledhill and Patience A. Schell, 1-20. Durham,

Green, Sarah N.C.: Duke University Press.

2018 "Crisis within a Crisis? Foreigners in Athens and Traces of Transnational Relations and Separations." In Critical Times in Greece: Anthropological Engagements with the Crisis, edited by Dimitris Dalakoglou and Georgios Agelopoulos, 102-16. London: Routledge.

Hamdy, Sherine, and Coleman Nye

2017 Lissa: A Story about Medical Promise, Friendship, and Revolution. Illustrated by Sarula Bao and Caroline Brewer. Lettering by Marc Parenteau. Toronto: University of Toronto Press.

Haskell, Thomas L.

1985a "Capitalism and the Origins of the Humanitarian Sensibility, Part 1." American Historical Review 90, no. 2: 339-61. https://doi.org/10.1086/ahr/90.2.339.

1985b "Capitalism and the Origins of the Humanitarian Sensibility, Part 2." American Historical Review 90, no. 3: 547-66. https://doi.org/10.1086/ahr/90.3.547.

Herzfeld, Michael

1985 The Poetics of Manhood: Contest and Identity in a Cretan Mountain Village. Princeton, N.J.: Princeton University Press.

1987 “'As in Your Own House': Hospitality, Ethnography, and the Stereotype of Mediterranean Society." In Honour and Shame and the Unity of Mediterranean Society, edited by David D. Gilmore, 75-89. Washington, D.C.: American Anthropological Association.

1992 The Social Production of Indifference: Exploring the Symbolic Roots of Western Bureaucracy. Chicago: University of Chicago Press.

1997 Cultural Intimacy: Social Poetics and the Real Life of States, Societies, and Institutions. New York: Routledge.

2012 "Afterword: Reciprocating the Hospitality of these Pages." JRAI 18, supp. 1: S210S217. https://doi.org/10.1111/j.1467-9655.2012.01773.x.

2016 "Critical Reactions: The Ethnographic Genealogy of Response." Social Anthropology 24, no. 2: 200-204. https://doi.org/10.1111/1469-8676.12310.

Hirschon, Renée

1992 “Greek Adults' Verbal Play, or, How to Train for Caution.” Journal of Modern Greek Studies 10, no. 1: 35-56. https://doi.org/10.1353/mgs.2010.0250.

2001 "Freedom, Solidarity and Obligation: The Socio-Cultural Context of Greek Politeness." In Linguistic Politeness across Boundaries: The Case of Greek and Turkish, edited by Arın Bayraktaroğlu and Maria Sifianou, 17-42. Amsterdam: John Benjamins.

2013 "Cultural Mismatches: Greek Concepts of Time, Personal Identity, and Authority in the Context of Europe." In Europe in Modern Greek History, edited by Kevin Featherstone, 153-69. London: Hurst.

Ingold, Tim

2011 “Introduction." In Redrawing Anthropology: Materials, Movements, Lines, edited by Tim Ingold, 1-20. Farnham, UK: Ashgate.

2012 "Introduction: The Perception of the User-Producer." In Design and Anthropology, edited by Wendy Gunn and Jared Donovan, 19-33. Farnham, UK: Ashgate. 
Jackson, Michael

1998 Minima Ethnographica: Intersubjectivity and the Anthropological Project. Chicago:

Keesing, Roger M. University of Chicago Press.

1992 Custom and Confrontation: The Kwaio Struggle for Cultural Autonomy. Chicago: University of Chicago Press.

Kirtsoglou, Elisabeth

2004 For the Love of Women: Gender, Identity and Same-Sex Relations in a Greek Provincial Town. Abingdon, Oxon: Routledge.

2018a "Commentary: Nomadic Ethics." In The New Nomadic Age: Archaeologies of Forced and Undocumented Migration, edited by Yannis Hamilakis, 221-30. Sheffield, UK: Equinox.

2018b “'We are all human': Cosmopolitanism as a Radically Political, Moral Project.” In An Anthropology of the Enlightenment: Moral Social Relations Then and Today, edited by Nigel Rapport and Huon Wardle, 133-50. London: Bloomsbury.

Kirtsoglou, Elisabeth, and Dimitrios Theodossopoulos

2018 "Empathy, as Affective Ethical Technology and Transformative Political Praxis." In Moral Anthropology: A Critique, edited by Bruce Kapferer and Marina Gold, 10432. Oxford: Berghahn.

Knight, Daniel M.

2012 "Cultural Proximity: Crisis, Time and Social Memory in Central Greece." History and Anthropology 23, no. 3: 349-74. http://dx.doi.org/10.1080/02757206.2012.69 7064.

2015a History, Time and Economic Crisis in Central Greece. New York: Palgrave Macmillan.

2015b "Wit and Greece's Economic Crisis: Ironic Slogans, Food, and Antiausterity Sentiments.” American Ethnologist 42, no. 2: 230-46. https://doi.org/10.1111/ amet.12127.

Knight, Daniel M., and Charles Stewart

2016 "Ethnographies of Austerity: Temporality, Crisis and Affect in Southern Europe." History and Anthropology 27, no. 1: 1-18. https://doi.org/10.1080/02757206.2015. 1114480 .

Marcus, George E.

1997 "The Uses of Complicity in the Changing Mise-en-Scène of Anthropological Fieldwork." Representations 59: 85-108. https://doi.org/10.2307/2928816.

2017 "Foreword: Lissa and the Transduction of Ethnography." In Lissa: A Story about Medical Promise, Friendship, and Revolution, written by Sherine Hamdy and Coleman Nye, illustrated by Sarula Bao and Caroline Brewer, lettering by Marc Parenteau, 11-14. Toronto: University of Toronto Press.

Marx, Karl, and Friedrich Engels

1998 The Communist Manifesto. New York: Penguin. Originally published in 1848.

Muehlebach, Andrea

2012 The Moral Neoliberal: Welfare and Citizenship in Italy. Chicago: University of Chicago Press.

Okely, Judith, and Helen Callaway, eds.

1992 Anthropology and Autobiography. London: Routledge.

Ortner, Sherry B.

1995 "Resistance and the Problem of Ethnographic Refusal." Comparative Studies in Society and History 37, no. 1: 173-93. https://doi.org/10.1017/S0010417500019587.

2015 "Too Soon for Post-Feminism: The Ongoing Life of Patriarchy in Neoliberal America." In De-Pathologizing Resistance: Anthropological Interventions, edited by Dimitrios Theodossopoulos, 116-35. London: Routledge.

Osella, Filippo, Roderick Stirrat, and Tom Widger

2015 "Charity, Philanthropy and Development in Colombo, Sri Lanka." In New Philanthropy and Social Justice: Debating the Conceptual and Policy Discourse, edited by Behrooz Morvaridi, 137-56. Bristol: Policy Press. 
Panourgiá, Neni

1995 Fragments of Death, Fables of Identity: An Athenian Anthropography. Madison: University of Wisconsin Press.

2009 Dangerous Citizens: The Greek Left and the Terror of the State. New York: Fordham University Press.

Papataxiarchis, Evthymios

1991 "Friends of the Heart: Male Commensal Solidarity, Gender, and Kinship in Aegean Greece." In Contested Identities: Gender and Kinship in Modern Greece, edited by Peter Loizos and Evthymios Papataxiarchis, 156-79. Princeton, N.J.: Princeton University Press.

1999 "A Contest with Money: Gambling and the Politics of Disinterested Sociality in Aegean Greece." In Lilies of the Field: Marginal People Who Live for the Moment, edited by Sophie Day, Evthymios Papataxiarchis, and Michael Stewart, 158-75. Boulder, Colo.: Westview Press.

2006 "Isaghoyi: Ta ahthi tis eterotitas." In Peripeties tis eterotitas: I paraghoyi tis politismikis dhiaforas sti simerini Elladha, edited by Evthymios Papataxiarchis, 1-85. Athens: Alexandreia.

2016a "Being 'There': At the Front Line of the 'European Refugee Crisis'-Part 1." Anthropology Today 32, no. 2: 5-9. https://doi.org/10.1111/1467-8322.12237.

2016b "Being 'There': At the Front Line of the 'European Refugee Crisis'-Part 2." Anthropology Today 32, no. 3: 3-7. https://doi.org/10.1111/1467-8322.12252.

2016c "Unwrapping Solidarity? Society Reborn in Austerity." Social Anthropology 24, no. 2: 205-10. https://doi.org/10.1111/1469-8676.12309.

2018 "Afterword: Pragmatism against Austerity: Greek Society, Politics and Ethnography in Times of Trouble." In Critical Times in Greece: Anthropological Engagements with the Crisis, edited by Dimitris Dalakoglou and Georgios Agelopoulos, 227-47. Abingdon, Oxon: Routledge.

Paxson, Heather

2004 Making Modern Mothers: Ethics and Family Planning in Urban Greece. Berkeley: University of California Press.

Poulimenakos, Giorgos, and Dimitris Dalakoglou

2018 "Hetero-Utopias: Squatting and Spatial Materialities of Resistance in Athens at Times of Crisis." In Critical Times in Greece: Anthropological Engagements with the Crisis, edited by Dimitris Dalakoglou and Georgios Agelopoulos, 173-87. Abingdon, Oxon: Routledge.

Rakopoulos, Theodoros

2014a "The Crisis Seen from Below, Within and Against: From Solidarity Economy to Food Distribution Cooperatives in Greece." Dialectical Anthropology 38, no. 2: 189-207. https://doi.org/10.1007/s10624-014-9342-5.

2014b "Resonance of Solidarity: Meanings of a Local Concept in Anti-austerity Greece." Journal of Modern Greek Studies 32, no. 2: 313-37. https://doi.org/10.1353/ mgs.2014.0040.

2015a “Solidarity Economy in Contemporary Greek: 'Movementality', Economic Democracy and Social Reproduction during Crisis." In Economy for and against Democracy, edited by Keith Hart, 161-81. Oxford: Berghahn.

2015b "Solidarity's Tensions: Informality, Sociality, and the Greek Crisis." Social Analysis 59, no. 3: 85-104. https://doi.org/10.3167/sa.2015.590305.

2016 "Solidarity: The Egalitarian Tensions of a Bridge-Concept." Social Anthropology 24, no. 2: 142-51. https://doi.org/10.1111/1469-8676.12298.

2018 "The Future of Solidarity: Food Cooperativism as Labour in Greece." In Critical Times in Greece: Anthropological Engagements with the Crisis, edited by Dimitris Redfield, Peter Dalakoglou and Georgios Agelopoulos, 202-16. Abingdon, Oxon: Routledge.

2012 "Humanitarianism." In A Companion to Moral Anthropology, edited by Didier Fassin, 451-67. Malden, Mass.: Wiley-Blackwell. 
Reed-Danahay, Deborah E., ed.

1997 Auto/Ethnography: Rewriting the Self and the Social. Oxford: Berg.

Rosaldo, Renato

1989 Culture and Truth: The Remaking of Social Analysis. Boston: Beacon Press.

Roseberry, William

1994 "Hegemony and the Language of Contention." In Everyday Forms of State Formation: Revolution and the Negotiation of Rule in Modern Mexico, edited by Gilbert M. Joseph

Rozakou, Katerina and Daniel Nugent, 355-65. Durham, N.C.: Duke University Press.

2012 "The Biopolitics of Hospitality in Greece: Humanitarianism and the Management of Refugees." American Ethnologist 39, no. 3: 562-77. https://doi.org/10.1111/ j.1548-1425.2012.01381.x.

2016a "Crafting the Volunteer: Voluntary Association and the Reformation of Sociality." Journal of Modern Greek Studies 34, no. 1: 79-102. https://doi.org/10.1353/ mgs.2016.0014.

2016b "Socialities of Solidarity: Revisiting the Gift Taboo in Times of Crises." Social Anthropology 24, no. 2: 185-99. https://doi.org/10.1111/1469-8676.12305.

2017 "Solidarity \#Humanitarianism: The Blurred Boundaries of Humanitarianism in Greece.” Ethnofoor 29, no. 2: 99-104. https://www.jstor.org/stable/26296172.

2018a Apo "agapi" kai "alilegii": Ethelontiki ergasia me prosfiges stin Athina tou proimou 21 ou aiona. Athens: Alexandreia.

2018b "Solidarians in the Land of Xenios Zeus: Migrant Deportability and the Radicalisation of Solidarity." In Critical Times in Greece: Anthropological Engagements with the Crisis, edited by Dimitris Dalakoglou and Georgios Agelopoulos, 188-201. Abingdon, Oxon: Routledge.

Schwanhäußer, Anja, ed.

2016 Sensing the City: A Companion to Urban Anthropology. Basel: Birkhäuser. Scott, James C.

1985 Weapons of the Weak: Everyday Forms of Peasant Resistance. New Haven, Conn.: Yale University Press.

1990 Domination and the Arts of Resistance: Hidden Transcripts. New Haven, Conn.: Yale University Press.

Shah, Alpa

2017 "Ethnography? Participant Observation, a Potentially Revolutionary Praxis." Hau Sutton, David

7, no. 1: 45-59. https://doi.org/10.14318/hau7.1.008.

2016 “'Let Them Eat Stuffed Peppers': An Argument of Images on the Role of Food in Understanding Neoliberal Austerity in Greece.” Edited transcript of a talk given by David Sutton on March 16, 2016, at the School of Oriental and African Studies, University of London. Gastronomica 16, no. 4: 8-17. https://doi.org/10.1525/ gfc.2016.16.4.8.

Sutton, David, Nefissa Naguib, Leonidas Vournelis, and Maggie Dickinson

2013 "Food and Contemporary Protest Movements." Food, Culture and Society 16, no. 3: 345-66. https://doi.org/10.2752/175174413X13673466711642.

Taussig, Michael

2011 I Swear I Saw This: Drawings in Fieldwork Notebooks, Namely My Own. Chicago: University of Chicago Press.

Theodossopoulos, Dimitrios

2015 “On De-Pathologizing Resistance.” In De-Pathologizing Resistance: Anthropological Interventions, edited by Dimitrios Theodossopoulos, 1-16. Abingdon, Oxon: Routledge.

2016a Exoticisation Undressed: Ethnographic Nostalgia and Authenticity in Emberá Clothes. Manchester: Manchester University Press. 
2016b "Philanthropy or Solidarity? Ethical Dilemmas about Humanitarianism in Crisis-Afflicted Greece." Social Anthropology 24, no. 2: 167-84. http://doi. org/10.1111/1469-8676.12304.

2017 “Exoticisation Undressed: A Graphic Review by the Author." JRAI 23, no. 2: 419 21. https://doi.org/10.1111/1467-9655.12614.

2019 "A Vision for Emberá Tourism: Graphic Art in the Service of Publicly Engaged Ethnography." Entanglements 2, no. 2: 7-26. https://entanglementsjournal.org/avision-for-embera-tourism/.

Forthcoming "Iphigenia's Sacrifice: Generational Historicity as a Structure of Feeling in Ticktin, Miriam Times of Austerity."

2014 “Transnational Humanitarianism.” Annual Review of Anthropology 43: 273-89. https://doi.org/10.1146/annurev-anthro-102313-030403.

Trundle, Catherine

2014 Americans in Tuscany: Charity, Compassion and Belonging. Oxford: Berghahn.

Williams, Raymond

1977 Marxism and Literature. Oxford: Oxford University Press.

1979 Politics and Letters: Interviews with New Left Review. London: Verso.

Žižek, Slavoj

2009 First as Tragedy, Then as Farce. London: Verso. 